\title{
Culture, Classicism, Community and Human Relations in Contemporary Arabic Fiction
}

\author{
Rashad Mohammed Moqbel Al Areqi* \\ Associate Prof. of English literature, Head of English Department, Faculty of Sciences and Arts, Al Mandaq \\ Albaha University, Saudi Arabia
}

*Corresponding Author: Rashad Mohammed Moqbel Al Areqi, Associate Prof. of English literature, Head of English Department, Faculty of Sciences and Arts, Al Mandaq Albaha University, Saudi Arabia

\begin{abstract}
Cultural and religious values are the main elements that determine the social behavior and human relationships in the community. Such cultural and religious values are responsible for a person's look at himself and others. Cultural and religious values put people in good or bad mould due to their attitude towards such values, whether positive or negative. When people are permeated with cultural and Islamic values that are marked with tolerance and coexistence, love, and mutual respect, community behaves in relevance with such concepts learned from their culture and religion, however, some persons ignore their cultural and Islamic values to fulfill their own earthly interests. This article is an attempt to go through some selected concepts/values and their relationship with each other and how such concepts/values establish human relationships. This article focuses on a significant literary work written by Ala Al Swani, Yaqoubian Building (2002), the best selling Arabic novel for the two years: 2002-2003. Yaqoubian Building penetrates deeply into cultural, social, political, sexual and religious relationships argued in the narrative of contemporary Egypt. How do people establish their relationships with others? This article found most relationships are controlled by self interest, be it business, social, religious, political, sexual, homosexual, etc. Cultural and Islamic values of Yaqoubian Building community are replaced by self or at best mutual interests. They are neglected by adhering to the materialistic culture of the west and self/mutual interests. Therefore, the indigenous/Islamic identity becomes stamped by the hybrid and globalized culture that may not pay much attention to the cultural and Islamic values in human relationships, even the closer relationships involved with the family members and friends fall apart in a community that recognizes only its own interests and believes in materialistic life of the west. Most relationships of Yaqoubian Building inhabitants showed selfishness of the higher class to make use of the lower class socially, politically, sexually, homosexually and religiously, simultaneously, the higher class showed no respect for the poor or regret for their sins.
\end{abstract}

Keywords: Culture, Community, Classicism, Relations, Contemporary, Arabic, Fiction, Interest.

\section{INTRODUCTION}

Naturally, human life is controlled by human relationships, even the animal kingdom is controlled by races and species. It is very important for a human being to keep such relationships between him and his parents, relatives, neighbors and community. Human kind is created as a social being in need for others. The differences between human beings are based on gender, position, race, tribe and/or power. How such relationships are established? Such relationships are supposed to achieve interest and satisfaction of two parties but sometimes one party attempts to monopolize such a relationship for self interest through the family connections, race, tribe, home or identity. The self interest involved with the higher class may use business, sex, or religion to achieve their goals which will definitely create radicalism in all aspects of people's lives whether they are religious, social or political.

Alaa Al Aswany is one of the contemporary Egyptian novelists who have addressed such issues and relations in his novel, Yaqoubian Building, which has been one of the bestselling novels for two years. He focuses on the contemporary Egypt traced in the narrative. The world of the novel represents a small community of Egypt. It is a world by itself. Through such a text, the author depicts many segments of the Egyptian community and their relationships. Many relationships are controlled by a 
host of concerns such as political position, sexual and homosexual interests, trading the fund benefits, and religious support for one group against other community segments. The novel also exhibits the political corruption, particularly that of police officers who may lead people to more radicalization practiced in the name of Islam and creating spirit of revenge in which the spirit of Islam disappears in favor of the spirit of revenge and terrorism reflected in intolerant acts and actions among the different classes of the community.

Al Swani's Yaqoubian Building has addressed openly the taboo of homosexuality in Arabic fiction. It breaks taboo barriers whether of homosexuality/sex or religion, or the state security taboo, including the ill- treatment of prisoners by police officers, particularly the religious prisoners. The novel establishes its own world that would not be controlled only by powerful rules and laws but also by the type of relationships adopted in the community.

\section{THE WORLd OF YAQOUbian BUILDING}

The Yaqoubian Building world is restricted to the narrative building people. Details do not exceed place boundaries which bring into mind all human rights and human violations. People are controlled by the influential rules and power. Human values vanish before powerful love, sex obsession, and domination in its different aspects. The novel reveals the world's mercilessness, heartlessness, and greediness for all kinds of love and lust. It is a world dominated by powerful individuals. In her review, Nana Asfour, an Egyptian critic and writer, pointed out that:

The mounting pressure of life down-at- the-heels leads to more than one act of violence and $\mathrm{Al}$ Aswany deftly builds up the narrative to the boiling point. But instead of ending his book with an explosive bang, one that might leave an indelible mark on the reader, the novelist chooses to keep things light, resorting to a Hollywood-style finale, where everything ties up nicely and happily. (New York Times, Arts News, 2007)

In one of her interviews with the Yaqoubian Building's writer, Pamela Nice (2006) asked about journalists' claim that the novel is the most read novel since Mahfouz's trilogy because of its break of sex taboo and police corruption. It also directly addresses sex, including homosexual relationships. Al Alswany, the novel writer, pointed out that "'why can't we say there is a following because the writing and story are good? Sometimes, discussing the political, social or other themes in a novel and crediting those for its popularity, is a way of dismissing it as worthy literature" (Al Jadeed, Vol. 12, 56-57, 2006). The good reputation of the narrative is due to its uniqueness as a good story as the author explained. It has been made a film under the same name: the Yaqoubian Building.

Yaqoubian Building tells about the contemporary Egypt depicted through the narrative characters with their different classes, relations and interests. They share the same building despite of their different classes, interests and cultures. The story addresses many characters and every one of such characters represents a world by itself, a full story narrated in detail. The Yaqoubian Building shows us two worlds: a higher class with its merits and demerits and a lower class with their sacrifice and struggle. Every group struggles to obtain a great benefit from the other even if such benefits come against human values and manners. The most significant thing for them is how to succeed in taking a great share out of others. Such interests may be not only financial but it could also be a satisfaction for lust in its varied forms: political, social, sexual or even homosexual. Ethics is the last thing they think about. Values and human rights are ignored or got isolated before their greediness and concerns. The differences between the two classes are striking. Some of them in high furnished apartments of the Yaqoubian Building while others living in small rooms in the building roof.

Moreover, the story tells about Taha Al Shazli, the doorman's son, who dreams of being a gentleman in the Police Academy. He finds out that his lower class will stand against fulfilling his dreams. He will be beaten and humiliated by the police officers whom he once dreamed to be one of them. The story also tells about Hagg Azzam who makes use of his power and money to reach up to high positions in the community. He has married a woman, as a second wife, to satisfy his sexual lust under his conditions and to run this marriage secretly. She succumbs to his request of marriage to help her son. In front of the community, he behaves piously while, behind Community's eyes, leading another life with the devil. He is a man who increases his power and money by deceit and dubious business dealings regardless of his illegal business relations with Kamal Al Fouli who helps Hagg 
Azzam to reach the People's Assembly illegally as a sort of trade interests and favors. In the prelude of his Book, Arab Culture and the Novel, Muhammad Siddiq (2007) pointed out that:

Arab Culture and the Novel explore the status and role of the novel in modern Arab culture. It postulates the historical experience of modern Egypt as largely representative of the general condition of other Arab, Islamic, and postcolonial nation-states, especially as these wrestle with the perennial quest for a viable sense of personal and collective identity in modernity.

Culture controls people behaviors and values so that the West knows this fact and therefore attempts to distort and hybridize the Eastern culture to cope up with its own life style. But people usually behave in relevance with their cultural values. Zaki Bey and Hassan Rashid, Hatim's father, are obsessed with the western culture because they have studied in France and saw progress in glorifying the western culture and the westerners' style of life. Rasheed speaks French with his family as a sign of civilization and progress. The novel shows that such characters are more open to the western cultural values. It also shows a sort of sympathy towards Hatim for his homosexuality that is due to his father's negligence and openness. Such sympathy extends to include Zaki Bey for his over romanticism and sexism connected with his life in France.

Edward Said, a well-known Palestinian critic, (1993) pointed out in his renowned book Culture and Imperialism how culture is a tool of imperialism to dominate nations. He states that "All cultures tend to made representations of foreign cultures, the better to master or in some way to control them. Yet not all cultures make representations of foreign cultures and in fact master or control them. This is the distinction, I believe, of modern western cultures" (p. 100). Yaqoubian Building is a world in which you find the higher class leaning to the western culture as a sign of civilization and progress, particularly, the figures such as Rasheed and Zaki. They come back to their country to practice the western style of life that makes them see in their culture an obstacle to satisfy their social and sexual desires in the name of openness to the more civilized culture, ignoring perhaps such cultural values of the West would be a source of destruction to their families and community and that their children will be torn between two kinds of cultures that reveal their characters as ambivalent and unable to adapt themselves with the community.

Another sort of relationship that breaks the taboo of homosexuality is the relationship between Abduh, the upper Egyptian married man, with Hatim Rasheed. Hatim Rasheed makes use of Abduh's need of money to have an affair in the bed with Abduh to help him with money that will help his family in a merciless world based on trading favors and benefits. Such a relationship breaks the taboo of homosexuality openly and makes readers sympathize with gays in a community in which religion and social conventions may not accept or encourage such an illegal relationship. Hatim Rasheed, half French and half Egyptian, is an editor of a French News paper (Le Caire). Abduh has lost his son and considers this event as a warning from God. It is a punishment for his illegal acts that go against Islam. He attempts to stop such an illegal relationship while Hatim Rasheed may not give up easily. Such relationships will be argued in detail in the present study.

\section{Classicism AND COMMUNity IN YAQOUBian BUILding World}

Taha el Shazli is the son of the Yaqoubian Building doorkeeper. He lives in shacks on the roof of the building. The poor just passes the stairs and the corridors of the building to the roof of the building. $\mathrm{He}$ is a real devout Muslim who prays to God to content him with mercy and protection. Taha's dream is to be a police officer and has exerted his efforts to achieve so. His efforts succeed to let him obtain a score of $98 \%$ without any sort of private tutoring. His unique marks arouse the envy and jealousy of the higher class families in the Yaqoubian Building whose sons could not obtain such marks. The higher class students' parents start to talk sarcastically to one another to congratulate the doorkeeper for his son's high score in the general secondary school certificate. Classicism voice is audible and the higher class families may not stand the success of the poor. Such higher class families always urge Taha's father to send his son to vocational learning to gain a job easily to help his father.

Taha's dream to join the police academy does not leave his mind and he struggles to do the best to achieve his dreams in a world that does not believe in the capacity of a human as it believes in the name of the family. The son of the doorkeeper should be a door keeper and the community will not give him an opportunity to achieve his dreams. Such a community looks at the poor as inferior and the poor does not need to compete with the sons of higher class families on the higher positions of the community: "that jobs in the police, the judiciary, and the sensitive positions in general should be 
given only to the children of the people who were somebody because the children of doorkeepers, laundrymen, and such like, if they attained any authority, would use to compensate for inferiority complexes and often neuroses they had acquired during their childhood" (p. 18). This is the community look at the contest of the poor for the higher positions in the community. They do not stand the stories of the poor's success. They believe that the doorkeeper's son, laundrymen's sons and other lower families' sons should inherit the lower jobs of their parents. The son of the lower family becomes a victim of the classicism of community. Even their places of living need to show their lower root. They always live in shacks on the roof of the building at their best and in the street at their worst.

Taha is a poor who wants to exceed the boundaries of his family poverty and aspires to be a police officer; however, the communal classicism hinders his efforts to be a police officer to compensate his family for the days of deprivation. He joined Abdeen Youth Club to keep his body in shape and to pass the physical fitness tests of police academy. All such efforts would not help in a community that only believes in the names of the families and the bribery that should be paid for the corrupted officers. His trust in God is big: "he finally believed that God would make his dreams come truefirst of all because he made the utmost efforts to honor God's commandments, observing the obligatory prayers and avoiding the major sins" (p. 20). God granted him success in secondary school as Almighty promised His good worshippers.

Life is hard, particularly for the poor who lives in contact with the higher class. Taha struggles in life for good living and good position that may compensate his family for the days of poverty and deprivation. However, the community starts to curse the Abdel Nasser's regime who offered free education for such poor. The higher class families are envious of giving the poor free education and erroneously claim that the Prophet (PBUH) said that "Teach not the children of the lowly" (p. 18). Despite Shari'a calls for justice, equality and education for all people and the first Ayah in Holy Quran calls the Prophet (PBUH) to read " قرأ باسم ربك الذي خلق ("Read! In the name of your Lord Who has created (all that exists)" (Surat 96. Al- Alaq). And the criterion upon which people are measured is their level of piety before Allah (SWT):

"Verily, the most honourable of you with Allah is that (believer) who has AtTaqwa [i.e. he is one of Al- Muttaqun (the pious)." (Surah 49. Al- Hujurat). It is not the matter of richness or poorness, blackness or whiteness, it is not the matter of higher class or lower class, and it is not the matter of race or tribe. Islam puts the poor like Salman Al Farsi and Belal Al Habashi, and Suhaib Al Romi on equal terms with other Muslims in Makka whose roots refer back to the higher class families in Makkah. Those are the genuine values and mannerisms of Islam. To find erroneous or deliberate claims that higher class community claims the discrimination of Islam between lower class and higher class, it is out of people's illusions to stabilize their discriminatory values. The Holy Quran Ayahs deny the behavior of the Prophet (PBUH) when he showed special concern with the higher class of Makkah in Surah Abasa and ignored the blind man, hoping the higher class families in Makkah would be a sort of protection and support to Islam in its cradle stage.

عبس وتولى "1" ان جاءه الأعمى "2" وما يدريك لعلى يزكى "3" أو يذكر فتنفعه الذكرى "4"

1-The Prophet, peace be upon him, frowned and turned away. 2. Because there came to him the blind (i.e. Abdullah ibn Umm- Maktum, who came to the Prophet, peace be upon him, while he was preaching to some Quraish chiefs). 3. And how can you know that he might become pure (from sins)? 4. Or he might receive admonition, and the admonition might profit him?" (Surah 80. Abasa). Islam does not encourage racism between the lower class and the higher one. However, Islam wants the people with their different classes to live on equal terms regarding rights and duties.

In the interview of the Police Academy, Taha shows his smartness to answer all the questions asked by the examiner, presiding general, who does not hesitate to show his admiration by Taha's answers. However, the last question which Taha does not expect to hear. It is about his father's job. He realizes in such situations, the community may not accept to give an opportunity to the son of the doorkeeper. He replies "a civil servant sir" (p. 58). Taha learns how to manipulate with the words to help himself to pass the test, but the bribery paid to the one who has to chop the application form may not be sufficient to save his application from this critical moment. The voice of the examiner comes to redress the balance about his father's job "a civil servant or a property Guard...Then he said in a low voice a property Guard, sir" (p. 58). 
The poor families are careful to raise their children on Islamic teachings. Taha is a religious man who takes care of the prayers and he always puts his trust in God, but the community may not give him an opportunity to be a good citizen. He knows that such jobs are given to the influential people who pay bribery or have some influential friends to take care of their applications. Taha realizes but very late that in a community of higher class, power and bribery, he may not gain an opportunity to join the police academy. Such jobs are only for the higher class families. Despite Taha's living in the shacks of the roof of the Yaqoubian Building, he has obtained the best score in general secondary school certificate that aroused the hate, jealousy and envy of the higher class of the building against him. The higher class families in the building start to curse the regime that gives such lower class families an opportunity for free education. "They should say 'No children of doorkeeper's and what they did are against the law, too." (p. 59). Here the reader is in contact with the misery of Taha who spares no efforts to join the police academy, whether at the the level of physical fitness or the academic preparation. All preparations may not help him to join the job he likes.

The community shows respect only for the powerful classes and the influential ones who own money and high positions in the community. As a result, Busayna gives Taha a tip "go off to an Arab country, earn some money, then come back here to live like a king ...make money, Taha, you'll get everything, but if you stay poor they'll walk all over you" (p. 59). Busayna realizes through her humble experience with the employers that the community may show its respect, only if you have money and power. The community keeps only the mutual interest relationships. Consequently, the first contact with the community has shocked Taha to let him feel the bitterness of injustice and discrimination. He knows now, even late, that there is no a place for the poor and the sons of the doorkeepers in the high social positions of the community. The reality of the community is realized by Busayna through her simple experience of the labor market. She has briefed the situation to Taha in words:

Look, Taha. I know I'm a year younger than you, but I've worked and work has taught me a few things. This country doesn't belong to us, Taha. It belongs to the people who have money. (The researcher's emphasis), If you'd had twenty thousand pounds and used them to bribe someone, do you think anyone would have asked about your father's job? (p. 59)

It is the first feeling of oppression and injustice that makes Taha stay awake all the night thinking about the interview, contempt and humiliation look of the presiding general, his words as a tape rewinding itself in the mind of Taha "Your father's a property guard, son?" "A property guard?"-an unfamiliar expression" (p. 60). It is the first traumatic experience of Taha. The job which he exerts his efforts to join, the police Academy, is the same job that makes him suffer severely. The words of Busayna "this country doesn't belong to us" show that the world of the poor and the lower class are still the world of ideals, values and commitment to the religious duties and mannerisms. The poor like Taha starts his childhood as a true believer who puts his trust in God and he always fulfills his religious duties and social responsibilities with relying on the God's willing and responding positively to the destiny of his God. Do you think the community will leave the poor, like Taha, to live in peace? The question will be answered throughout this research.

The values of the community are taken from its culture and religion. If the community shows no concern about its religion and culture, it will leave a larger space for the globalized customs and materialistic look to dominate the community. The culture of the higher class is permeated by the privileges gained from the people so that the higher class and the sons of the higher class will be educated on that base. In the eyes of the higher class, the poor has no right to compete with the rich for high positions or a better life. Consequently the higher class shows no respect or appreciation to the poor, but they always stand in the way of their progress. In this sense, the culture is built on mutual interest between the two classes. If the poor class empowers itself to get the money and the position in the community that may help it to trade the benefits with the higher class, the lower class will move to the higher class in the name of mutual interests. Regrettably, in the eyes of the higher class and the hybrids, the Islamic values and rituals become a mark of the weak and the poor who find in a religion a sort of condolence and relief for their misery and poverty. Eventually the rich and the powerful class do not hesitate to disparage the religious values, the cultural concepts, and the conventions of the community because they like to catch up with the western civilization and globalized identity. 
Taha wants to complain to the judiciary or president, but in vain, "Busayna laughed bitterly. "Complain about who and to who? Do as I say and no more useless ideas. Work hard, get your degree, and don't come back here till you're rich" (p. 60). To change the situation and reach such people, Taha needs to work hard and get rich. The tone of contempt and humiliation still rings in Taha's ears "You want to get into the police, you son of a doorkeeper?!! The son of the doorkeeper wants to be an officer? That's a good one, I swear!" (p. 60). The poor has lost the trust in the community and its justice because the higher class shows only disrespect and humiliation for the inferior class. The values which govern the higher class are the mutual interest values and the power of money.

\section{Social AND SEXUAl Relationships}

The human relationships are controlled by the medium a human lives in and the childhood experiences, particularly that of traumatic stamp. Another sort of relationships in the narrative is the sexual one that it takes the form of sexual harassment/exploitation. Sexual exploitation may appear because of trading the interests: sex for money or sex for only enjoyment or sometime a sort of harassment because of weakness, poverty, and powerlessness of one of the parties of the relationship as sometimes such a sexual relationship comes as a result of the negligence of the parents for their son or daughter left to be raised with the servants or the bad community members. Undoubtedly the western style of upbringing has its negative influence upon the children particularly the parents who are involved with illegal relationships or glorify the open/western sexual relationships whatever they are: the same sex relationships (homosexual relationships) or the illegal relationships that are out of the circle of marriage. The higher class realizes their fault very late, after they have lost their sons.

Hatim Rasheed is a son of Dr. Hassan Rasheed who accomplished his study in the West, particularly in Paris, and came back to practice what he studied/saw abroad in his country, in spite of the different values and conventions of his country. He has married Janette, a French woman who recognized her during his study in France and brought her home with the only son, Hatim. The father's admiration of the western culture and tradition made him speak at home in French and looked at his culture and tradition from an inferior perspective. Rasheed does not hesitate to put progress synonymous for the West. Rasheed is always tied with his work that leads him to be one of successful figures in the country and his wife spends most of her time working for the French embassy as a translator. The parents glorify the materialistic life of the west that leads them, at the end, to lose their son. They run behind fame and fortune, ignoring their familial responsibilities towards their child. They never leave enough time to their little son who is in need for orientation in such a critical stage of his life: the life of childhood in which the one's experiences and personality are shaped. Hatim is left in the hands of the servants to be raised; almost they are not the good hands that the parents may rely on. Hatim suffers so much of loneliness and alienation, being deprived of his parents' passions in such a critical age. Hatim's childhood is shaped by an illegal/ homosexual relationship with a servant who spends the most of his time with the boy during the parents' absence. He is a Nubian servant; his name is Idris, who serves at Rasheed's home for living. This sort of a relationship is developed to take the illegal tendency "Idris started kissing Hatim on his face and neck and whispering 'I love you', you're beautiful. I love you" (p. 75).

Adris starts to make use of the boy sexually in the absence of the parents and their clear negligence of the son encourages Adris to continue this homosexual relationship that affects psychologically the life of the boy in the future. The parents keep no eye on him that encourages Idris to exploit the boy sexually. "I did that because I love you. If you love me, don't tell anyone what happened. If you tell them, they'll beat you and throw me out. Your father may put me in prison or kill me and you'll never see me again" (p. 75). Idris left the house after the death of Hatim's father and his mother passed away two years later to leave their son suffering alienation and loss. Hatim becomes a victim of his parents' carelessness, they never pay close attention to their son, but they leave him for the servant who has destroyed his psychology and taken advantage of his parent's absence to exploit the boy sexually and shape his early childhood with traumatic experiences which accompany him throughout his life. This homosexual relationship reveals the boy weak, powerless and the absence of the parents' orientations make the boy ignorant about what right/wrong is.

Hatim continues his homosexual relationships with many men. He becomes the one who searches for men to satisfy his homosexual instincts. At last, he finds Abd Rabbuh, the military man, who is in need for money to help his family. Hatim starts to seduce Abd Rabbuh to respond to his sexual 
demands. This illegal relationship is prohibited in Islam and the community will not accept such an illegitimate relationship. Hatim offers many temptations to Abd Rabbuh to keep him home for longer time. If Abd Rabbuh starts to feel the sin of his behavior, the need for money comes to silence his tongue and hinder his escape from Hatim's trap. However, his son's death is the cry that awakens Abd Rabbuh to consider his misbehavior and his sins. It is the punishment of God for his sins as he claimed. This sort of a relationship is based on mutual interest. It is for Abd Rabbuh a sort of money benefit to send it to his family and it is for Hatim a sexual instinct satisfaction that may not be satisfied only with homosexuality. The rich people make use of the poor ones and exploit them sexually. This is very clear in such a homosexual relationship of Hatim with Abd Rabbuh who may not respond to such a relationship without the temptations of Hatim's money. If he feels the sin and the conscience remorse as a Muslim and as a conservative person, Hatim will bring him back to the money temptations. Abd Rabbuh realizes the look of the community to such an illegitimate relationship. It is rejected by Islam teachings and community conventions alike.

Another situation for such sex exploitation is Zaki Bey's illegal relationships that know no barrier. Zaki has established many illegal relationships with women from different classes: higher or lower. He makes use of his position and power to exploit the high class women sexually. He does not hesitate to make relationships with different classes in the community: secondary school girls or university females, even he has an affair once with a female beggar. As a result, one of the prostitutes who Zaki has brought to his house to have an affair with her, has robed his sister's ring who supposes to repair and return back to his sister. The ring story is the beginning of trouble with his sister who does not want to forgive him or forget her ring.

Another example of the sexual harassment, it is the story of Busayna with her employer. Busayna has suffered very much from the community which has no mercy. Her employer, Mr. Talal, searches how to satisfy his whims through the illegal relationships, exploiting the need of the poor females to negotiate their agreement. He exploits the beautiful and poor girls sexually and makes use of their urged need to make them succumb to an illegal relationship with him. Her father's death leaves a void which may not be filled easily. Her family is in urgent need for money and she struggles to find a job to help her family. Her mother's words ring in her head "your brothers and sisters need every penny you earn. A clever girl can look after herself and keep her job" (p. 42). Such words make Busayna attempts to find a job as soon as possible, however, the world around her is merciless and heartless, and it may not distinguish between a male and a female. The poor as Busayna sacrifices her reputation for money and the business men get, in turn, pleasure. It is a mutual interest albeit the purpose is different. The community exploits the poor and the needy people sexually, whether males or females. Hatim enforces Abd Rabbuh to have a homosexual relationship with him for money and Busayna finds herself enforced to respond positively to her employer's whims for money and to keep her living in his stores, " Talal pounced on her from behind, flung his arms around her hard enough to hurt her and started rubbing up against her and playing with her body without uttering a single word ...the whole business was over in about two minutes" (p. 45). Busayna has lost her trust in the community and the relationship is controlled by money and sex. Abd Rabbuh and Busayna feel the sin and it is not easy for them to hold back. Their Islamic raising and their conservative families make the situation hard for them and they see in such a behavior a sin that needs repentance. Both indulge into an illegitimate relationship, albeit different kinds of relationships, which are prohibited in their religion and culture because they are in need of money for their families.

Hagg Azzam is one of the important figures in the community. His wealth and elegance prepare him to be the Big Man of Sulaiman Basha Square and the people come to get their business done and settle their misunderstandings. Hagg Ezzam's money facilitates his marriage of a widow with a son in need for good living and education. Hagg Azzam makes use of her critical situation to put unfair terms for this marriage. It is another sort of mutual interest. For Souad Gaber, it is a sort of sex for money and Hagg Azzam is actually in search for pleasure and sex satisfaction. Busayna and Souad sacrifice their happiness to help their families and get money for noble purposes as Abd Rabbuh who may not be able to resist the temptations of money who are in need for to help his family. The community makes use of such poor people who are in urgent need for money and lead them on a road they do not imagine themselves to walk on. The powerful and wealthy people show no mercy upon the needy and the poor, particularly the weak females. The community has indulged into illegal relationships, whether, that relationships of the employer with the workers or that one which organizes the 
relationships with the members of the family. Sometimes such relationships are based on mutual interests. Definitely one of the parties is enforced in such a relationship because of family needs of money.

Busayna has moved to work for Zaki Bey el Dassouki because he pays well. Taha will not agree on Busayna's decision to work in the apartment of Zaki Bey who has notorious reputation in the area because of the illegitimate relationships with women and the habit of alcoholic drinking. Any woman will work in his apartment, she will disrepute herself, "sure, he's got a bad reputation and he likes women, but he pays me six hundred pounds a month..." (p. 118). The urgent need for money makes Busayna thinks only in money to support her family, without paying much attention to her reputation. It is a sort of trading interests between the higher class and the lower class, between the rich and the poor. It is sex for money. The poor female does not look for enjoyment as much as they are in search for money to support their families. However, the rich are looking, in turn, for sensual and sexual pleasures. The story of Talal, the businessman, and Zakey Bey, are a good evidence of the higher class's sexual harassment of the poor females. Souad Gaber, the second wife of Hagg Azzam, has sacrificed her real happiness with her son to marry Azzam and benefited from his money to raise her son and educate him well. The second relationship, Souad and Azzam, it is a legitimate relationship. However, it is an unfair one regarding the difference in age between Souad and Hagg Azzam and the unfair conditions of such a marriage. She has to leave her son in another province to satisfy Azzam's desires.

Since he finds out that she is pregnant, he uses a variety of ways to persuade her to abort her fetus, but in vain. He talks to her brother, he even brings his friend, el sheikh el Samman represented Azzam's a spiritual guide, to persuade her to abort herself and he confirms her it is not a sin, however, he could not persuade her to abort her fetus. Then he uses dirty ways to abort her and eventually, he has managed to abort her. This is a real example of the family relationship, a husband with his second wife; it is a sort of trading mutual interests. It is sex for money for the female, and it is sex for pleasures for the male. Hagg Azzam pretends to be a pious man, however, his business, social and familial ties reveal his genuine nature. He takes care only of his reputation and how to grow his money even in illegal ways.

Another type of family relationship is the relationship between Zaki Bey and his sister, Dawlet. She makes use of her brother losing her ring to kick him out of their father's a apartment without paying attention to the close relationship between her and her brother which represented by blood and brotherhood and Zaki does not want to bring a scandal to the family by fighting over their father's legacy. He prefers to keep himself away from his sister, Dawlet. It is not enough to his sister Dawlet to put her hands on the apartment which her brother Zaki has a share of it, but also she brings the police to his office which Zaki considers as a home after his sister has sent him out of the apartment in Yaqoubian Building to disrepute him in finding him with one of the females in a love affair. The relationship of Dawlet with her brother, Zaki, is not that a healthy relationship or that a relationship which reveals the closer familial relationship that expresses love and brotherhood. It becomes a sort of business and how can make use of her brother's legacy to keep it for herself. It is a sort of selfishness. Most of the relationships which appear in Yaqoubian Building are overwhelmed by mutual interests in which of one the parties is the great benefiter, almost the higher/business class, and the other party is enforced to offer concessions for the urgent need of money. The higher class and the rich one if may not get benefit from the lower class, whatever the benefit, whether make use of the poor one sexually or homosexually, they will not help them. It is very clear in the illegal relationship of Hatim with Abdu Rabbu or the legal relationship of Hagg Azzam with his second wife, Souad Gaber. The main purpose of such a marriage is not establishing a family, but to satisfy Hagg Azzam's sexual instincts in the name of marriage. The relationships whatever they are, a family relationship: a brother with a sister, a husband with a wife or a social one as Busayna with the business men or Abdu with Hatim manifest the merciless and materialistic community that may not pay something for nothing.

Hatim's father and Zaki Bey are influenced by the western style of life. Both studied in France and the glamour of Paris life left a stamp in their personal lives. However, Hatim's family leaves Hatim under the care of a servant who leads him to homosexuality which finds himself unable to unfetter of its shackles. Eventually, he has put an end to his life unable to satisfy his homosexual instincts. Zaki's over romanticism leads him to live with the prostitutes, drinking and listening to the romantic songs, particularly French ones. Such a behavior encourages his sister, Dawlet, to kick him out of the 
apartment and disrepute him to put her hands on his office and other estates under the plea of his misconduct. The world of Yaqoubian Building brings out into life different social classes and different sexual leanings.

\section{BUSinESS AND Political Relationships}

The stink of political corruption appears clearly in the suspicious relationships of the leaders of the government, Kamal el Fouli, and Hagg Azzam who compete with the other candidates to reach the dome of People's Assembly. Kamal el Fouli's ambitions and greediness drive him to reach to a high position in the government despite his decent origin. He was able to keep his position in all the people's political structures despite the changes in the government regime. At last, he managed to become the secretary of the patriotic party and the organizer of the whole elections of Egypt. Hagg Azzam, in the name of providing help to Muslims in his region, he wants to put himself a candidate for Kasr el Nil Constituency, "I hope that the Patriotic Party will agree to nominate me and I'm yours to command, Kamal Bey, for anything you may need." (p. 83).

El Fouli will not offer his services for nothing. He seems the man who has a high trust in his capacity to make Azzam win the elections of the constituency. No doubt El Fouli realizes the capability of Azzam to pay whatever he wants. This relationship is a pure business relationship controlled by trading the mutual interests, "A whole 'rabbit'? A million pounds, Kamal Bey? That's a huge amount! ... I don't take all that for myself. I'm just the postman-I take from you and deliver to others" (p. 84). The political corruption becomes rampant in all the government offices and many government men run and make use of their positions to run dubious deals with the business men and rich people who are in need for political help or they are ambitious to reach very high positions in the government.

Hagg Azzam has paid a huge amount to el Fouli because he knows he is the controller of the political elections and his connections with the country men may guarantee a seat to Azzam in the People's Assembly. Azzam is the man who behaves under the Islamic garment and talks with a tongue of a pious man who is very careful to serve his people. He does not hesitate to manipulate with the Islamic language using Islamic Hadith and Quran to support his situations. They use the words such as "God willing" "“Congratulations, Hagg! Come on, let's read the Fatiha. May the Lord be generous to us and grant us success!" (p. 85). They play with the words that may show their good intentions while they really break the values of Islam by paying/receiving bribery to reach their dubious goals. The politicians like el Fouli, and the the business men like Azzam; have exploited the manifestations of Islam to fulfill their own goals and the only goal that opens the gate for them to grow up their funds by gaining a high position in the government.

The second candidate, Abu Hameida, is another corrupt business man who competes with Hagg Azzam to win the elections. He also makes use of his wealth and trade to gain the poor people's hearts through charitable works. The business men, like Azzam and Abu Hameida, know well that the community by nature may trust the Islamic figures and the men of Islamic values and charity. Abu Hameidah uses his charitable projects as propaganda to win the elections of his constituency, "Despite these setbacks, the project achieved enormous success and helped thousands of Muslim women to adopt modest dress... Hagg Abu Hameida went on record as saying that he'd sworn to set aside a large sum of money to be spent on charitable works in the hope of winning the favor of God, Almighty and Glorious" (p. 87). Both candidates make use of the Islamic discourse to gain the hearts of the poor who really puts their trust in God to vote for them. It is not enough for them to use manipulative ways/words to reach the People's Assembly but also make use of the Islamic language and Islamic discourse to cover their intentions that showing no more than their own interests. Abu Hameida makes use the woman garment project to let a large segment of women to vote for him. However, "rumors constantly circulated that Abu Himeida was one of Egypt's biggest heroin dealers, that the Islamic project was a money-laundering front, and that the bribes he paid to top officials protected him from arrest." (p. 87).

One of the political means to fail the candidates is the rumors that certainly will affect the course of election for the favor of one of them and the opposite propaganda that seek in the dirty history of the candidates to make the ordinary people lose their trust in such people. It is one of the tools used by the political world of election. Hagg Azzam wins the elections, it does not mean he is the qualified person or the appropriate one but because he has paid in advance for the decision makers like el Fouli to gain the elections and guarantee its results. Both candidates have notorious reputation of their suspicious 
deals and their illegal means of wealth growing. Whoever will win the election definitely he is not the best who represents the people's interests but he actually in search of his own interests and how to guarantee the means of protection, particularly when he will be one of the decision makers, at least, very closed of them.

El Fouli may not provide something to anyone without return. He has taken a million, only to let Hagg Azzam win the People's Assembly elections. The political power reveals itself in the capacity of el Fouli to control the results of elections in favor of the powerful party. It does not matter if the elected is a good or a bad person or he will serve the people or not, or he will run after his interests and attempts to grow up his trade and money even in dubious deals or not. El Fouli shows his great confidence to run the elections the way he likes because the Egyptians are submissive and they may accept any party.

Our Lord created the Egyptians to accept government authority. No Egyptian can go against his government. Some peoples are excitable and rebellious by nature, but the Egyptian keeps his head down his whole life long so he can eat. It says so in the history books. The Egyptians are the easiest people in the world to rule. The moment you take power, they submit to you and grovel to you and you can do what you want with them... (p. 84-85)

Here the reader may realize the political corruption. It is not the right man in the right place but the business man is in the government. The relationship of Azzam with el Fouli is controlled by mutual interests. If the businessman or the higher class man attempts to get rid of his supporter, they will not give him an opportunity to do so; otherwise, he will lose his position, money and reputation. The world of politics is merciless and dirty, and it may not tolerate any sort of violation of the agreements with the powerful and the influential politicians. The politicians, including el Fouli, who helped Azzam to reach the People's Assembly, will not let Azzam grow up his money without giving them their share in all his big deals. They ask Hagg Azzam to pay them a quarter from the profit of the Japanese Agency. Otherwise, he has to victimize all his estates and interests. El Fouli is only the beginning of a long series of corruption. They work under the name of the Big Man. Azzam insists to meet the Big Man and at last el Fouli will let Azzam meets the Big Man and see the sort of life he lives and the security guards who take care of him. The author makes the Big Man anonymous and his identity unknown to drag the reader attention to the domination of the powerful men over the decision makers and, in turn, they only share the money of the business men who seek for good position and growing trade. Everywhere you may find a Big Man who protects the higher class, the business men's trade and interests for an agreeable share of their profits.

Another example of political corruption, it is the story of Taha in detention. Taha spends his school days dreaming of getting a position in the Police Academy. He has prepared himself academically by getting the best score which arouse the jealous and hatred feelings of the higher class in the Yaqoubian Building so as the son of the door man does not deserve to get a high score in secondary school examinations. Despite Taha has passed all the tests, he could not get a position in the Police Academy. Law does not prevent him from joining the Academy but the people's classicism and discrimination which are practiced away of the law will not give him an opportunity that may let the poor get out his poverty circle and helps his family and community. This is another sort of political corruption.

Taha's dream to be in the Police Academy will be a horrible nightmare in which he was tortured to confess something he does not recognize. The torture and criminal actions in the detentions of the police centers and prisons will not leave any place of tolerance in the life of Taha. These places of detentions are a sign of another political corruption. Such places do not recognize mercy or tolerance only torture and killing. The police officers represent the law and the power which no one dares to stand against.

\section{COMmunity AND Religious Relationships}

Taha was raised in an observant family which devotes their time in praying and show respect to the God's legislations. Taha appears subservient to his God since his childhood, his faith in God's help is limitless and he believes that it will lead him to success in his life. Since he could not join the Police Academy, he makes use of his high score to select a good college that fits his score in secondary school. He has joined the economic department and got new friends and fresh class mates. There is no surprise to find Taha establish friendships with the people who are on equal terms of his class and 
culture. He starts to have some friends who lead him to connect with Gamma'a Islamia and lead him to Sheikh Shaker who is the Imam of one of the mosques in Madint Nassr.

Taha's commitment to Islam and rituals of Islam simplify the mission of his friends to lead him to be one of the Islamists who carries out the commands of God on earth. Islamic Jihad considers one of the forgotten concepts in the Islamic countries and needs to be revived in our daily activities as Taha and his friends claimed. Many of Gama'a Islamia members have been tortured in detentions and some of them died of detention and torture. The idea of librating them from the police centers is the duty of the faithful Muslims. This is the idea of Taha and his friends, and to fulfill that goal, they go in demonstrations to pressure the government to release their brothers. The tie which keeps Taha with his friends is the religious one. It is that relationship which calls for Islam and its teachings. However, Taha may not find an opportunity to do something for his religion because the police attacks his room in the night and leads him to detention and torture.

The torture in detention humiliates Taha and turns him into a monster. Taha could not forget the traumatic experience he went through in detention. "They humiliated me, Master. They humiliated me till I felt the dogs in the street had more self-respect than me. I was subjected to things I never imagined a Muslim could do." (p. 68). Taha is exposed to painful torture which has left physical and psychological scars that passing time may not heal easily. He gets out the detention thinking about one thing, it is how to take revenge from the police officers who tortured him physically and psychologically and to avenge for his honor, "They violated my honor ten times, Master. Ten times." (p. 170). The police men and statesmen have practiced all types of torture and they do not spare any part of his body. Taha feels dead as soon as they have violated his honor. The police torture turns the good man and the religious one to a radical one who thinks only in taking revenge for his honor, even if his revenge will take the cover of Islamic Jihad. Taha gets out of the prison heartbroken, humiliated and he does not want to meet the people or go to the mosque for prayers. He is only concerned to avenge himself from the people who torture him. As a result, he asks Sheikh Shaker to help him to take his revenge from the police officers who are in charge of his detention and torture. Sheikh Shaker will send him to a training camp to be prepared to carry out a suicidal operation against his tormenters. He may remember them only from their voices because the police officers keep Taha's eyes closed by a piece of cloth, fearing that Taha will see their faces and may think of taking revenge from them in the future. The police officers in detention enforce him to call himself Fawziya, a name of a woman, to let him suffer psychologically as well.

I'm dead now. They killed me in detention. When they trespass on your honor laughing, when they give you a woman's name and make you answer with your new name and you have to because of the savagery of the torture. . . They called me Fawziya. Every day they used to beat me and make me say, 'I'm a woman and my name is Fawziya.' You want me to forget all that and go on living? (p. 190)

Taha's relationship is to find an opportunity to revenge for his honor. He spends his time thinking about this goal which he endeavors to achieve as soon as possible. Radicalism and extremism come as a reaction for the violation of statesmen to the dignity of the Islamists in detention, represented by different apparatuses of the state. Taha was dreaming of getting an honorable job to help himself and bring respect to his family. However, he could not join the job he spends his life dreaming of. He was humiliated when they rejected his application for the Police Academy and the same apparatus will cause misery to Taha that leads him at last to carry out a suicidal operation against the police officers who violate his honor in detention and stand against his life dreams. The narrative reveals the ugly face of the police officers and their horrible style of torture in detention, particularly their torture of the Islamic group. Everywhere there is a Big Man who may not let the poor achieves their goals and he works on keeping the poor in the circle of poverty which Taha spends his life struggling to get out of such a circle.

Taha does not exceed the circle of his friends and family, whether his friends in university classes, or his contact with the lower class friends, who Taha shares with them many things such as Islamic values and culture, his religiosity and his look at life in general. Taha becomes a victim of a merciless community which rejected him as a gentleman struggling to gain the best score in secondary school, overcome the hindrances of poverty and limited potentialities. He is a victim of the torture of the policemen who change his life to hell and leads him into misery and revenge. At last, he could take his revenge but he has lost his life. Yaqoubian Building is a world by itself. You find the son of the 
doorman, the business man, the religious man, the journalist like Hatim, the hypocrites who misuse the appearances of Islam to reach their goals in life while they go against Islam by their behaviors. Their look wearing the beards and holding the beads in their hands or wearing the Islamic dress and using the Islamic language may delude the public, but their acts go against Islam. Hagg Azzam is a bad example of a religious, a social, and a political man who manifests himself as a pious man who fears God and simultaneously, he breaks the teachings of God in his daily acts and actions. His spiritual father, sheikh el Samman, may not hesitate to help him in his unjust works, by releasing an Islamic Fatwa that serves Hagg Azzam. El Samman attempts to persuade Hagg Azzam's second wife to abort herself responding to the terms of marriage contract. Sheik Shaker seems to makes use of Taha's traumatic and painful experience to send him to carry out a suicidal operation against the policemen. All relationships in Yaqoubian Building are controlled by the type of mutual interests, leaving the cultural values, social conventions, and religious manners aside. It is a world of self/mutual interests.

Mutee Al Sarory (2014) pointed out in "Contextualization of the Islamic Language in Abdul Rahman Munif's Cities of Salt Trilogy" how the authors of novels misuse the Islamic language (IL) and Islamic appearance in their texts which only serve the western culture and distortion of Islamic character. Al Sarory traces, in his research, many models of such illegal exploitations for the Islamic appearance to fulfill their self interests or distort the genuine essence of Islamic characters to appear such characters as opportunistic, and destructive for the Islamic and cultural values. Mutee stated:

In novels, especially Arabic ones, there are characters that represent Muslims in appearance as well as in social and religious positions. Some of such characters are the characters of Imams of the mosques, Sufis, Qur'an teachers, Da'wa people (i.e. callers of Islam), etc. Such characters are abundant in Arabic novels. Many Islamic critics describe such characters as Islamic despite the distortion that such characters undergo in many Arabic novels, as those critics themselves point out. Bereighish states that: 'novelists have always distorted the Islamic character. Instead of depicting the pious good man, they depict him based on western Crusade perceptions as a dark man, with certain rituals, traits, having no connection with life; his appearance is incompatible with his character. They may also depict the Imam of a mosque preaching people but simultaneously blackmailing and exploiting them, using cunning schemes' (1994: 27)'. (qtd. in Mutee, P. 17).

The appearance of Islamic characters in the texts are not a mark of their religiosity, but sometimes the high class figures misuse such appearances and manifestations to delude the public and to gain their sympathy to vote for them in the elections, whatever such elections are. In Yaqoubian Building, It is clear enough in the political competition between Hagg Abu Azzam and Hagg Abu Hamida to win a seat in the People's Assembly. They know the public by nature respond to the Islamic speech and appearances so that each one is very careful to show his Islamic manifestations and Islamic projects offered to the people. They use all means to win the elections, legal or illegal ones, bribery and scandals whatever to win a seat in the People's Assembly. The victory is for the one who knows well the one he is in charge of such elections and the candidate is ready to pay whatever to the decision makers to win the elections. Hagg Azzam's pre-arrangements with el Fouli, the man who is in charge of the elections in the entire Egypt lead him to win the elections. The relationship between el Fouli and Hagg Azzam is the mutual interest relationship. Azzam has paid a million to win the election. Eventually he has managed to win the election and started a new business deals with the Big Man who is a symbol of the decision makers in the political life in Egypt and a symbol of corruption in the sectors of the government.

\section{CONCLUSION}

The cultural and Islamic values of the community suppose to lead the people's behaviors and the kinds of relationships to better. However, Yaqoubian Building, the small community of the contemporary Egypt, seem to ignore the cultural and Islamic values to give space for the life of self interest, at the best, and the mutual interests relationships at the worst. They pay no attention to their cultural and Islamic values. However, the narrative showed the resentment of the higher class to the previous regime which gave the lower class an opportunity in good education and honorable living. Different relationships of the Yaqoubian Building are controlled by the power and mutual interests whatever such relationships: social, sexual, homosexual, political, business...etc., namely, one the two parties misuses his power and influence to enforce the other party to succumb to his illegal demands, 
definitely, the weak and the poor one are enforced to work only for the powerful and higher class interests, ignoring the legal demands of the lower class or trading the mutual interests which is almost in the benefit of the higher and powerful class.

The research revealed the social relationships of the community fragile and vulnerable even the closed ones: between a husband and a wife, a brother and a sister, a friend and his friend, an employer and the workers, the religious man, who supposes to set a good example of good Muslim, with the public. In the narrative, all the relationships showed no respect and appreciation to the God's orders and the power of law if they stand against the higher class' own interests. This is clear enough in the community of Yaqoubian Building which was led by self interests and the urgent need of the poor to sacrifice their cultural and Islamic values for money to help their families. The culture of the community teaches the higher class how to be greedy and jealous of the poor success. The most important thing for the higher class is how to make use of the poor class sexually, homosexually, politically and socially, only to be a source of happiness to the higher class which knows only the language of self interest or mutual interest at the best.

The western style of life led Hatim's parents to practice the French language in the house and with the members of the family, and glorify the western culture, so that they look only for their success in a materialistic world which the parents practiced and experienced in France, ignoring the cultural and Islamic values of the community that lead them eventually to leave their son with a servant who exploits their son, Hatim, sexually. The research found that the author seems to reveal a sort of sympathy with violation of cultural values and Islamic teachings regarding Hatim who becomes homosexual and a victim of their parents' negligence and French culture. He also showed his sympathy with Taha whose right and honor have been violated in the police detentions and then he revealed his violence, revenge, and radicalism against the merciless community which destroyed Taha psychologically and physically under the different types of torture: verbal and physical. The message of the novel is that the community may create the good citizen or the bad one. If the community is led by the culture of coexistence and tolerance and love and the community finds the good ones who care for the poor, definitely respect and appreciation of the Islamic and cultural values will be prevailing and vice versa. The research showed that the community of Yaqoubian Building is torn by classicism and discrimination against the poor, the lower class, and the result reveals conflicting of interests and the class struggles for self interests or mutual interests. The higher class appeared greedy, selfish, merciless, and heartless, it attempts only to dominate the poor/lower class socially, politically, sexually, homosexually and culturally. The higher class trades the interests but it may not give something for nothing. If the western style of life controls the relationships, the materialistic look will control our culture and our Islamic values will disappear. No wonder, to find the gays, over sex obsession, materialistic culture, Islamic and cultural violations, selfishness, hate, hatred, and envy prevailing in the community.

In addition, the study showed the language of self interest is prevailing and the law of interest is the controller of the higher/lower class relationships. Taha and Busaina, Abdu Rabbu, Souad Gaber could not find kind hearts, and helpful hands that may help them to raise their families away of violation of cultural and Islamic values. However, they had to sacrifice their honor for money which they were in urgent need for. The feelings of sins and conscience remorse may overturn their life upside down. The narrative showed this sort of regret and feeling of sin, only from the side of the lower class which considers the Islamic teachings in their daily activities and reveals their fear of God. However, the political corruption stink is rampant in all political elections, police centers, and governmental institutions, and it dominates most of business dealings, social and sexual relationships. Hagg Azzam, Hagg Abu Hamida, el Fouli do not hesitate to use the Islamic manifestations/appearances and the Islamic language in their dealings to deceive the simple people and make use of them for their benefit. Behind the success of the business men and the growing of the business deals are a Big Man, the narrative showed the Big Man as an unknown one, who is waiting for his share in all business deals and the series of corruption is very long, it has no end. Yaqoubian Building people's relationships reveal a gap between poor and rich, between western cultured people and eastern cultured ones, a husband and a wife, a brother and a sister, an employer and a worker...etc. Classism is very striking in a community that believes only in power of money and influential positions. Such a community utilizes lower class socially or sexually to achieve its own interests regardless of the sacrifices of over trodden class to live an honorable life. 


\section{REFERENCES}

[1] Al Aswany, Alaa. (2004). the Yaqoubian Building. Translated by Humphrey Davies. Harper Collins eBooks: American University in Cairo Press.

[2] Allen, Roger. (2003). An Introduction to Arabic Literature. Cambridge University Press.

[3] Allen, Roger and Richards. S. D. (2008). Arabic Literature in the Post-Classical Period. Cambridge University Press.

[4] Al Sarory, Mutee. (2014). Contextualization of the Islamic Language in Abdul Rahman Munif's Cities of Salt Trilogy. Ph. D thesis, Faculty of Social Sciences and Humanities, University of Kebangsaan, Malaysia.

[5] Asfour, Nana. (2007). The Yaqoubian Building- Review. New York Times.

[6] Badawi. M. M. (2006). Modern Arabic Literature. Cambridge University Press.

[7] Cachia, Pierre. (2002). Arabic Literature- An Overview. Routledge Curzon Taylor and Francis Group.

[8] Nice, Pamela. (2006). A Conversation with Alaa al-Aswany on "The Yacoubian Building. Al Jadeed, Vol. 12. 56-57.

[9] Said. Edward. W. (1993). Culture and Imperialism. Vintage Books: New York.

[10] Siddiq, Mohammad. (2007). Arab Culture and the Novel Genre, Identity and Agency in Egyptian Fiction. Routledge: London and New York.

\section{AUTHOR'S BIOGRAPHY}

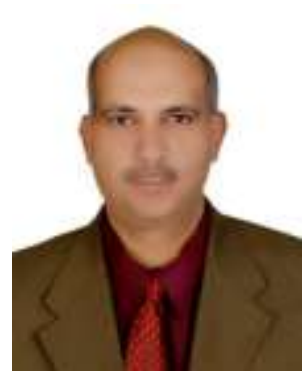

Rashad Mohammed Moqbel Al Areqi, was born in 1970, Taiz, Yemen. He got his PhD. Degree in English Literature in 2008, Putra University, Malaysia. He studied an intensive course in Contemporary American Literature, University of Louisville, Kentucky, USA, from June 17 to July 30, 2011. He got promoted to Associate Professor of English Literature in 2015, Albaha University, Saudi Arabia. The author works for Sana'a Community College in Yemen. However, as part of his sabbatical leave, he is now the Head of English Department, Faculty of Sciences and Arts, Al Mandaq, Albaha University. He is also a member of editorial board of different international journals as well as a reviewer. He is a Member of Editing Board of the Journal of Humanities, Albaha University and a Member of the Scientific Research Deanship Board, Albaha University. He has published many articles in varied international journals. His research interest areas are: English Lit., American Lit., Postcolonial Lit., Comparative Lit. Australian and Canadian lit. Arabic and Islamic Lit. World Lit., Literary theory/ Criticism, Identity and Gender, Race and Racism, etc.

Citation: Rashad Mohammed Moqbel Al Areqi "Culture, Classicism, Community and Human Relations in Contemporary Arabic Fiction" International Journal on Studies in English Language and Literature (IJSELL), vol 5, no. 12, 2017, pp. 68-81. doi:http://dx.doi.org/10.20431/2347-3134.0511007.

Copyright: () 2017 Authors. This is an open-access article distributed under the terms of the Creative Commons Attribution License, which permits unrestricted use, distribution, and reproduction in any medium, provided the original author and source are credited. 